\title{
A study on the Effectiveness of online mode of education during the covid-19 pandemic through the awareness and attitude of teachers
}

\author{
${ }^{1}$ Sanjay Dey, ${ }^{2}$ Amita Patra, ${ }^{* 3}$ Dillip Giri and ${ }^{4}$ Viswanath Reddy \\ 1 Associate Professor, UG College of Teacher Education, Baripada, Odisha, India \\ 2 Scientist (Home Science), Krishi Vigyan Kendra, Balasore, Odisha, India. \\ 3 Senior Adviser-Institutional Planning and Quality Assurance, Institute of Dental Science, Jammu (JひK), India \\ ${ }^{4}$ Senior Data Scientist and Consultant-Accreditation, Eupheus Consultancy Pvt. Ltd, Balasore, Odisha, India
}

\begin{abstract}
Context: Due to the COVID-19 pandemic the schools were shut all across the world. Globally, over 2.5 billion children and 30 million teachers were out of the classroom during the Academic Year, 2019-20 \& 2020-21. As a result, the process of imparting education has changed drastically, with the distinctive rise of online learning, whereby teaching is undertaken remotely and on digital platforms. Many previous pieces of research suggested that online learning has been shown to increase the motivation of the learners, and therefore they take less time to understand a concept. Additionally, it is very dynamic in the sense it gives much autonomy to the learners as well as teachers. However, being a new system of teaching and learning has opened many challenges for the stakeholders of education. Objective: The purpose of this study is to explore the System Approach of the online mode of education during the covid-19 pandemic through the awareness and attitude of teachers. Methods: Exploratory Survey Research and a retrospective cohort study design are used to conduct the study. The study population consists of 300 teachers of secondary schools. This research design was opted due to the exploration of various ideas, notions, and thoughts of the respondent of the study. This research study followed standard ethical protocol. Statistical Procedure: The data was arranged, organized, tabulated, and analyzed after the completion of data collection. Mean, SD, $t$-Test, ANOVA and Tukey's HSD (Honestly Significant Difference) was computed. Results: It is found that the teachers working in rural area schools are conservative towards the online system of learning. The teachers of English medium Schools/Private Schools are more aware than their counterparts working in the Govt. Schools. The mean awareness score of female teachers is below the male teachers for all cohorts. Across the demographic characteristics, the teachers were demanding more structural training to bring effectiveness into this system. Internet connectivity was found a big issue in the transactional process. Teachers were doubtful about the credibility of assessment through this online system. Conclusion: The study identified many important concerns on the curriculum transaction through online learning during Covid 19 Pandemic. It has been proved very significant research concerning the cognitive and behavioral aspects of the teachers. Another important innovation of this study was the identification of a system approach in teaching and learning through online platforms.
\end{abstract}

Keywords: Online Education, Awareness, Attitude, Educational Technology, System Approach, Effectiveness, SWOT

\section{Article Publication}

Published Online: 20-Jan-2022

*Author's Correspondence

8 Dillip Giri

8 Senior Adviser-Institutional Planning and Quality Assurance, Institute of Dental Science, Jammu $(\mathrm{J} \& \mathrm{~K})$, India 10.31305/rrijm.2022.v07.i01.002

$\triangle$ myidea.matters.2019[at]gmail.com

C 2022 The Authors. Published by RESEARCH REVIEW International Journal of Multidisciplinary. This is an open access article under the CC BY-

NC-ND license

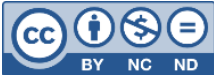

(https://creativecommons.org/licenses/ by-nc-nd/4.0/)

\section{Introduction}

COVID-19 was declared as a global epidemic by WHO (World Health Organization) in February 2020. Starting in China in Nov-Dec, 2019, it has been proved a severe epidemic in the century which has spread to all world countries and so far taken the lives of more than four million people across the world (September 2021). Alone in India close to half a million deaths were reported. Its multi-variant appearance and unique form of the infectious 
system have perplexed the medical community and pharmacy companies. This pandemic compelled the schools to shut all over the world and over 2.5 billion students and 30 million teachers were out of the classroom. Although lockdown and social distancing brought positive outcomes, they also led to the immediate closure of educational institutions (Figueiredo et al., 2020). During this lockdown \& shut down period the only way to teach the students was through online mode and on digital platforms.

Online teaching is an innovation of Educational Technology (ET). ET has made a huge advancement in recent years (Garrison, D. R., Anderson, T., \& Archer, W. 2001). For many years it has been an effective medium for teaching adult learners in the form of distance education or continuing education. The innovation of ET has become the most convenient medium to impart education to students during this pandemic (Chatterjee \& Chakraborty, 2020; Dhawan, 2020). The research conducted by Fedynich (2014) \& Wedenoja (2020) found that the innovations of ET in the form of virtual learning, digital learning, artificial intelligence, and online interactive platforms are economical and brilliant for imparting mass education. Recent research conducted by Mishra, Gupta \& Shree (2020) investigated the effectiveness of physical and online classrooms. The findings of the study said that the opinion of the students towards online classes was better than the physical classes. This finding was supported by the research conducted by Nguyen (2015) and Bojovic (2020) and Patricia (2020) in online classes the students enjoy the highest form of autonomy related to their time scheduling, giving feedback, clearing doubts, and searching online resources. If it is planned systematically (Nguyen, 2015), it can be the best form of pedagogy (Van Ben Berg et al. 2006). The strength of online learning is it can create a hybrid or blended learning environment where both face-to-face and e-learning can bring effectiveness to the educational experience of learners (Steen 2008). Online education is always economical and cost-effective (Dziuban, etal.2005). ET has brought a lot of advances and innovations in the teaching, learning, and assessment process. In the last decade, the popularity of online education has grown exponentially (Cevher-Kalburan, N. (2011).

\section{Context}

Due to the COVID-19 pandemic, many radical changes have occurred in the social, economic, political, and educational systems of world countries. Thanks to disruptive digital technology the essential systems of functioning of the Govt./Private machinery were continued on digital platforms. When digitalization was started in the educational system it was not well accepted by the students, teachers, parents, and educational planners. But gradually it was proved as the panacea for the maladies arising from the epidemic. Today it is the most impactful system in creating autonomous learners through ample opportunities for receiving information and creating knowledge. Online classrooms have become the only best alternative to impart education to learners across all levels during the COVID-19 pandemic. Therefore, it has indeed brought new life and possibilities to the challenging situations created from the COVID-19 pandemic.

However, despite many advantages, the online system of education has certain limitations too, such as in the virtual platforms the slow learners do not receive the support they normally receive from their peers (Schroeder,2010, Patricia, 2020). Moreover, online classes are not too beneficial for small children (Youn, et al. 2012), since they are too immature to receive their education through online mode hence mostly depend on their parents in their learning. Therefore, it is required the parents mostly the mother is available during the online mode of teaching (Copeland, W. E. et al,2020). Again online system of education cannot help the teachers and students with mild disabilities (Lassoued, Alhendawi, M., \& Bashitialshaaer, Peters, et al. 2020). A study conducted by Lembani, Gunter, A., Breines, M., \& Dalu (2020) found that the online system of education during COVID-19 has divided the learners as privileged and underprivileged, specifically concerning their residential background and socio-economic status. In rural areas, both teachers and students face problems accessing the quality of internet connection compared to their urban counterparts. Therefore, they face a lot of challenges to deliver and receiving the content through online mode (Alhendawi, 2020). Some other studies conducted by CAO et al., 2020; Islam, Barna, Raihan, Khan, \& Hossain, 2020)" reported that the COVID-19 lockdown drastically affected the mental, emotional health of many students. The prolonged lockdown forced the students 
to stay home for a long time lacking their physical socialization. As a result, many of them were found suffering from acute stress, anxiety, and depression (Essbek \& Rabeyron, 2020).

\section{Rationale}

Online learning was not a choice or a chance to continue the education of billions of learners across the world during the Covid 19 pandemic when the global lockdown was enforced. Rather, it was the only hope for the Governments to continue the education of their future generation. Gradually it became the sole medium of teaching, learning, \& assessment of students learning outcomes for all levels of education since the pandemic was taking time to end up its dreadful impact on the health of the people. One of the advantages of the online mode of learning, it is comparatively cheaper than face-to-face learning (Wedenoza, L (2020), Yildiz, E.p. \& Isman, A. 2016). Online mode of education is also flexible in terms of time, a complication, of course, giving feedback, etc. Fedynich (2014). Though it was a fact that online learning helped the Govt. and other stakeholders to manage the drawbacks of a zero academic session yet many educationists and social scientists have shown their concerns about the quality and effectiveness of online teaching and assessment.

Online education is not beneficial for slow learners because they have a deficiency in concentration, patience, and interaction with teachers and peers (Stephen, C., \& Plowman, L. (2008). Again, the quality of interaction between teachers \& students on the online platform is not up to the mark concerning non-verbal communication, instant feedback, and remedial teaching (Kerry, T., \& Farrow, J. (1996). Further, the assessment which is conducted online is again questionable for its credibility because it is obvious that while writing a test online the child may take the help of his/her family members for answering the test questions. Even the project work given online does not fetch much quality, since these lack creativity of the students. There is a difference between online learning and face-to-face learning concerning the motivation, interest, interaction, and satisfaction of the learners and teachers (Bignoux \& Sund, 2018). Konca, Ozel, E., \& Zelyurt (2016) in their research conducted on the perception, attitude, and awareness of teachers in Malaysia reported that only $47 \%$ of rural teachers and $63 \%$ of urban teachers are comfortable with the online system of teaching. This finding is also supported by Lindahl \& Folke (2012), Yurt \& Kalburan (2011).

Therefore, many researchers have recommended that to develop the quality and effectiveness of the online mode of teaching the teachers must receive proper training in designing the course material considering the individual differences that exist within their students (Chem \& Chang, 2006). Another concern of online teaching is to teach young school-age students, which is a mostly very challenging task for a teacher who may be excellent in face-toface teaching, as young children depend on their parents while studying online and accessing learning resources online (Schroeder \& Kelley, 2010 and Youn, et al 2012). Another disadvantage of learning through online platforms is that students often miss the interaction between their peers, laboratory work, and library study (Patricia 2020). During the COVID-19 period, many studies were conducted in Bangladesh, China, the UK, India, the USA, Greece, France \& Canada, etc on the status quo, quality, effectiveness, and challenges of the online system of education. The outcomes of the research reported that, during the lockdown, students detached from their schooling resulted suffering from stress, mental disorder \& tensions (Khan, et al. 2020, Jiang 2020, Essadek 2020, Kaparounaki, Patsali, M. E., Mousa, D. P. V., Papadopoulou, E. V., Papadopoulou, K. K., \& Fountoulakis 2020, Savage, et al. 2020).

Studies conducted by Bojovic, et al. (2020) \& Nguyen (2015) reported that students achieve better while studying physical classrooms than online mode. Some studies found that many teachers face difficulties in teaching online (Bojovic, Z., Bojovic, P. D., Vujosevic, D., \& Suh, J. (2020), because, they generally do not attend the refresher courses or orientation programs, where the latest development in education are discussed by the resource persons (Kalogiannakis 2010, Mishra, et al. 2020). After careful investigation of the available literature, the researchers understood that the online mode of learning has both advantages and drawbacks. However, these are mostly contextual, not fundamental. Undoubtedly, an online system of teaching and learning will be playing a very 
significant role in the future education system, because due to air pollution many natural hazards are happening and also going to occur on a severe scale in the future. As a result, there are many possibilities that in near future the human race will face varieties of epidemics similar to Covid 19. These situations will force our students to stay at home for attending schools online for a long time in an academic year. Therefore, the online mode of education will be playing a significant role in the future education system. Hence, the Govt. machinery in collaboration with private bodies has to work on the system approach of online Education. The first task towards improving the effectiveness and efficiency of online education is to develop the digital competencies of our teachers and school administrators. The teachers are the backbone of any education system. Their awareness and attitude towards a new system of Education is a very important criterion for getting good outcomes. Therefore, it is indispensable for the Govt. and other educational or social action agencies/Research bodies to work collaboratively on this area. As found from the literature, there are many studies which are conducted on the awareness and attitude of teachers on online teaching/digital competencies. But none of the studies has focused on the system approach of the same which lead to an evidenced-based SWOT (Strength, Weakness, Opportunities, and Threats) analysis. Evidence-based SWOT analysis is a qualitative approach to a social issue. This analysis gives strength to the outcome of the research and extends the scope of the research for future researchers. In the present research, the researchers have tried their best to investigate the system approach of online education through the variables.

\section{Research Objectives}

The objective of the study research was to understand the awareness level of teachers of the effectiveness of online education and to evaluate their attitude towards the same through various factors concerning their gender, professional qualification, Educational background, location of the school, their experience in teaching and their knowledge of online resources. Also, the researcher tried to find out the relation between teachers' level of awareness and depth of attitude of the effectiveness of online teaching. The studies also investigated the system approach of online education through the qualitative data received from the respondents. The last objective of the study was to conduct a SWOT analysis on the present status of the online system of Education.

\section{Research Methodologies}

\section{Sampling method}

Secondary school teachers mostly from the secondary schools of Northern India participated in this research through an online survey platform. These teachers were identified through the purposive sampling method. The teachers were categorized equally concerning their demographical characteristics. The sample distribution table is given below.

Table:01\# Sampling distribution

\begin{tabular}{|c|c|c|c|}
\hline \multirow{2}{*}{$\begin{array}{c}\text { Sample } \\
\text { (Secondary School Teachers) }\end{array}$} & \multirow[t]{2}{*}{ Category } & \multicolumn{2}{|c|}{$\begin{array}{c}\text { Frequency \& Percentage in the } \\
\text { Study }\end{array}$} \\
\hline & & $\mathbf{N}=300$ & $100 \%$ \\
\hline \multirow{2}{*}{ Gender } & Female & 150 & $50 \%$ \\
\hline & Male & 150 & $50 \%$ \\
\hline \multirow{2}{*}{$\begin{array}{l}\text { Professional } \\
\text { Qualification }\end{array}$} & Trained Teachers & 150 & $50 \%$ \\
\hline & Untrained Teachers & 150 & $50 \%$ \\
\hline \multirow{2}{*}{ Types of Schools } & Teachers from English Medium Schools & 150 & $50 \%$ \\
\hline & Teachers from Hindi Medium Schools & 150 & $50 \%$ \\
\hline \multirow{3}{*}{ Educational Background } & Arts Background & 100 & $33.30 \%$ \\
\hline & Science Background & 100 & $33.30 \%$ \\
\hline & $\begin{array}{c}\text { Allied Background } \\
\text { (Commerce, Art \& Craft, SUPW, IT, etc) }\end{array}$ & 100 & $33.30 \%$ \\
\hline \multirow{2}{*}{ Location of School } & Urban Area & 150 & $50 \%$ \\
\hline & Rural Area & 150 & $50 \%$ \\
\hline \multirow{3}{*}{ Teaching Experience } & $5-10$ Years & 100 & $33.30 \%$ \\
\hline & $10-15$ Years & 100 & $33.30 \%$ \\
\hline & 15 years and Above & 100 & $33.30 \%$ \\
\hline \multirow{2}{*}{$\begin{array}{l}\text { Knowledge of Online } \\
\text { Resources }\end{array}$} & Urban Secondary School Teachers & 150 & $50 \%$ \\
\hline & Rural Secondary School Teachers & 150 & $50 \%$ \\
\hline
\end{tabular}




\begin{tabular}{|c|c|c|c|}
\multirow{2}{*}{$\begin{array}{c}\text { Knowledge of Online } \\
\text { Resources }\end{array}$} & Female Teachers & 150 & $50 \%$ \\
\cline { 2 - 4 } & Male Teachers & 150 & $50 \%$ \\
\hline
\end{tabular}

\section{Research Instruments}

The teachers were surveyed through an online questionnaire and requested them to give their reactions to the questions concerning their knowledge and attitude of the online system of Education. In addition to the quantitative analysis of the data, the study also identifies the qualitative opinion of the respondents. The study was conducted through the proper ethical protocol. The questionnaire on the attitude of teachers towards online teaching had two open-ended questions. The first question was to receive the opinion of the teachers on the strength \& weaknesses of online education and the second was to get the opinion of the teachers about their suggestions to strengthen the system of online education.

\section{Major Findings}

The findings of the study are submitted in two segments. In the first one, the quantitative analysis results related to the awareness and attitude of teachers of online education. The second analysis was the respondents' opinion on their experience of practicing online education in their schools during Covid 19 lockdown periods.

\section{a) Findings from Quantitative Data Analysis}

Table:02\# Quantitative analysis of Data

\begin{tabular}{|c|c|c|c|c|c|c|c|c|c|c|c|}
\hline \multirow[t]{2}{*}{ Variables } & \multirow[t]{2}{*}{$\begin{array}{l}\text { Demographic } \\
\text { Characteristics }\end{array}$} & \multicolumn{4}{|c|}{$\begin{array}{c}\text { Awareness level of Teachers } \\
\text { on the Effectiveness of Online } \\
\text { Teaching }\end{array}$} & \multicolumn{3}{|c|}{$\begin{array}{l}\text { Attitude level } \\
\text { Teachers on the } \\
\text { Effectiveness of } \\
\text { Online Teaching }\end{array}$} & \multicolumn{3}{|c|}{$\begin{array}{c}\text { Correlation of the Awareness } \\
\text { and Attitude of Teachers on } \\
\text { the Effectiveness of Online } \\
\text { Teaching }\end{array}$} \\
\hline & & $\mathrm{N}$ & M & SD & $\mathrm{t}$ & M & SD & $\mathrm{t}$ & $\begin{array}{l}\text { Co- } \\
\text { relation } \\
\text { Value }\end{array}$ & $\begin{array}{l}\text { Co- } \\
\text { varianc } \\
\text { e Value }\end{array}$ & $\begin{array}{l}\text { Significance } \\
\quad \text { of } \\
\text { correlation }\end{array}$ \\
\hline \multirow{2}{*}{ Gender } & Female & 150 & 74.71 & 3.16 & \multirow{2}{*}{8.55} & 74.29 & 4.29 & \multirow{2}{*}{7.19} & 0.76 & 10.30 & $\begin{array}{c}\text { High } \\
\text { Correlation }\end{array}$ \\
\hline & Male & 150 & 79.67 & 3.19 & & 80.28 & 3.32 & & 0.89 & 9.39 & $\begin{array}{l}\text { Very High } \\
\text { Correlation }\end{array}$ \\
\hline \multirow{2}{*}{$\begin{array}{l}\text { Professional } \\
\text { Qualification }\end{array}$} & $\begin{array}{l}\text { Trained } \\
\text { Teachers }\end{array}$ & 150 & 84.95 & 3.015 & \multirow{2}{*}{6.67} & 85.14 & 3.62 & \multirow{2}{*}{9.13} & 0.90 & 9.79 & $\begin{array}{l}\text { Very High } \\
\text { Correlation }\end{array}$ \\
\hline & $\begin{array}{l}\text { Untrained } \\
\text { Teachers }\end{array}$ & 150 & 65.24 & 3.15 & & 65.37 & 3.74 & & 0.91 & 10.61 & $\begin{array}{l}\text { Very High } \\
\text { Correlation }\end{array}$ \\
\hline \multirow{2}{*}{$\begin{array}{l}\text { Types of } \\
\text { Schools }\end{array}$} & $\begin{array}{l}\text { Teachers from } \\
\text { English Medium } \\
\text { Schools }\end{array}$ & 150 & 85.06 & 3.008 & \multirow{2}{*}{6.11} & 85.33 & 3.59 & \multirow{2}{*}{2.33} & 0.87 & 9.35 & $\begin{array}{l}\text { Very High } \\
\text { Correlation }\end{array}$ \\
\hline & $\begin{array}{l}\text { Teachers from } \\
\text { Hindi Medium } \\
\text { Schools }\end{array}$ & 150 & 65.1 & 3.08 & & 65.39 & 3.41 & & 0.88 & 9.17 & $\begin{array}{l}\text { Very High } \\
\text { Correlation }\end{array}$ \\
\hline \multirow{3}{*}{$\begin{array}{l}\text { Educational } \\
\text { Background }\end{array}$} & $\begin{array}{c}\text { Arts } \\
\text { Background }\end{array}$ & 100 & 69.52 & 3.05 & & 69.42 & 3.44 & & 0.87 & 9.03 & $\begin{array}{l}\text { Very High } \\
\text { Correlation }\end{array}$ \\
\hline & $\begin{array}{c}\text { Science } \\
\text { Background }\end{array}$ & 100 & 84.53 & 2.904 & & 84.71 & 3.59 & & 0.78 & 8.07 & $\begin{array}{c}\text { High } \\
\text { Correlation }\end{array}$ \\
\hline & $\begin{array}{c}\text { Allied } \\
\text { Background } \\
\text { (Commerce, Art } \\
\text { \& Craft, SUPW, } \\
\text { IT, etc) }\end{array}$ & 100 & 70.1 & 3.19 & & 70.32 & 3.025 & & 0.87 & 8.27 & $\begin{array}{l}\text { Very High } \\
\text { Correlation }\end{array}$ \\
\hline \multirow{2}{*}{$\begin{array}{l}\text { Location of } \\
\text { School }\end{array}$} & Urban Area & 150 & 79.94 & 3.18 & \multirow{2}{*}{2.19} & 80.35 & 3.12 & \multirow{2}{*}{2.97} & 0.87 & 8.59 & $\begin{array}{l}\text { Very High } \\
\text { Correlation }\end{array}$ \\
\hline & Rural Area & 150 & 69.93 & 3.15 & & 70.2 & 3.24 & & 0.84 & 8.56 & $\begin{array}{l}\text { Very High } \\
\text { Correlation }\end{array}$ \\
\hline $\begin{array}{c}\text { Teaching } \\
\text { Experience }\end{array}$ & $5-10$ Years & 100 & 79.91 & 3.05 & & 80.64 & 3.14 & & 0.92 & 8.78 & $\begin{array}{l}\text { Very High } \\
\text { Correlation }\end{array}$ \\
\hline
\end{tabular}




\begin{tabular}{|c|c|c|c|c|c|c|c|c|c|c|c|}
\hline & $10-15$ Years & 100 & 84.89 & 3.12 & & 85.25 & 3.42 & & 0.89 & 9.39 & $\begin{array}{l}\text { Very High } \\
\text { Correlation }\end{array}$ \\
\hline & $\begin{array}{c}15 \text { years and } \\
\text { Above }\end{array}$ & 100 & 80.09 & 3.032 & & 80.12 & 3.14 & & 0.84 & 7.93 & $\begin{array}{l}\text { Very High } \\
\text { Correlation }\end{array}$ \\
\hline \multirow{2}{*}{$\begin{array}{l}\text { Knowledge } \\
\text { of Online } \\
\text { Resources }\end{array}$} & $\begin{array}{c}\text { Urban } \\
\text { Secondary } \\
\text { School Teachers }\end{array}$ & 150 & 84.95 & 3.015 & \multirow[t]{2}{*}{2.36} & 85.04 & 3.54 & \multirow[t]{2}{*}{2.05} & 0.90 & 9.56 & $\begin{array}{l}\text { Very High } \\
\text { Correlation }\end{array}$ \\
\hline & $\begin{array}{l}\text { Rural Secondary } \\
\text { School Teachers }\end{array}$ & 150 & 59.6 & 3.041 & & 59.55 & 3.58 & & 0.98 & 9.09 & $\begin{array}{l}\text { Very High } \\
\text { Correlation }\end{array}$ \\
\hline \multirow{2}{*}{$\begin{array}{l}\text { Knowledge } \\
\text { on Online } \\
\text { Resources }\end{array}$} & Female Teachers & 150 & 69.93 & 3.25 & \multirow{2}{*}{4.14} & 70.37 & 3.28 & \multirow{2}{*}{4.34} & 0.89 & 9.42 & $\begin{array}{l}\text { Very High } \\
\text { Correlation }\end{array}$ \\
\hline & Male Teachers & 150 & 74.53 & 2.98 & & 74.71 & 3.86 & & 0.89 & 10.18 & $\begin{array}{l}\text { Very High } \\
\text { Correlation }\end{array}$ \\
\hline
\end{tabular}

The table above represents the results of the quantitative analysis of Data. It is found that the mean awareness level of teachers of online teaching is above average for most of their demographic characteristics. In some cases, it is found that the respondents possessed an excellent level of awareness of online education. It is identified that the male teachers, professionally trained teachers, teachers from English medium schools, teachers from a science background, teachers from the secondary schools located in the urban area, and the teachers having 10-15 years of teaching experience were found excellent in the awareness of online education system compared to their counterparts. Additionally, the teachers from urban secondary schools were found better aware than their counterparts working in rural secondary schools on their knowledge of online resources. It is also found that male teachers have better knowledge of online resources than female teachers. Major findings related to the mean attitude level of teachers on online education show that the male teachers, the professionally trained teachers, and the teachers from English medium schools were found to strongly agree on the effectiveness of online education during the COVID-19 lockdown period.

It is also found that the teachers from English medium schools, teachers from a science education background, and urban secondary schools were more positive in their attitude towards teaching students through online mode during the COVID-19 crisis. Again the teachers having teaching experience between 10-15 years were having a more positive attitude in this regard. The study reported that the teachers from urban secondary schools were more positive in their attitude towards online education. So far as the correlation between the awareness and attitude of teachers on the effectiveness of online education is concerned, it is found that there was a very high correlation between the awareness and attitude of the respondents under various demographic characteristics. These shows the findings are consistent and reliable from the research point of view.

\begin{tabular}{|c|c|c|c|c|}
\hline & 1 & 2 & 3 & Total \\
\hline $\mathrm{N}$ & 100 & 100 & 100 & 300 \\
\hline$\Sigma x$ & 6952 & 8453 & 7010 & 22415 \\
\hline Mean & 69.52 & 84.53 & 70.1 & 74.717 \\
\hline$\Sigma x^{2}$ & 484224 & 715367 & 492406 & 1691997 \\
\hline Std.Dev. & 3.05 & 2.904 & 3.1861 & 7.5896 \\
\hline
\end{tabular}




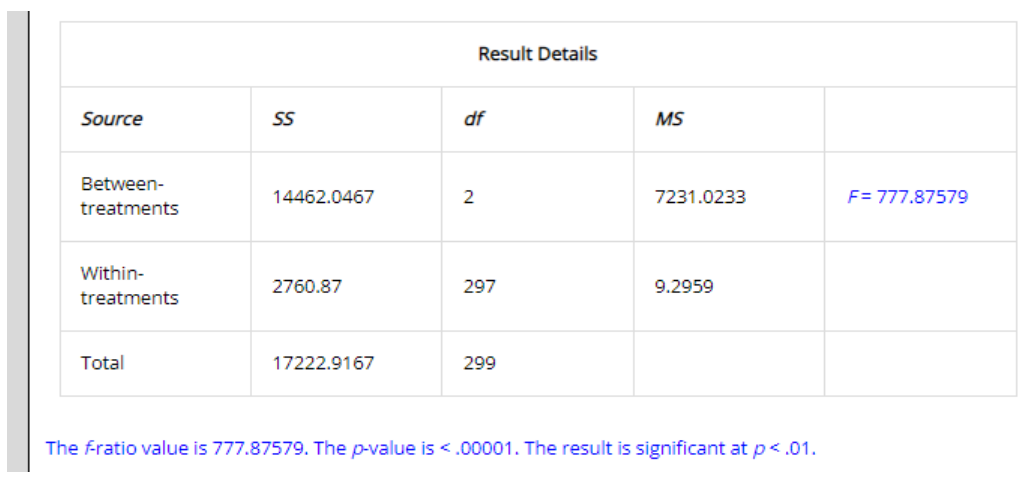

The above table compares the awareness of teachers with several teaching backgrounds concerning the effectiveness of online education. This was analyzed through ANOVA. The F ratio is found 777.88 and accordingly, the $\mathrm{P}$-value is $<.0001$. Therefore, the result is significant at $\mathrm{P}<.01$. It is concluded that so far as the teaching background is concerned the teachers differ significantly in their awareness level on the effectiveness of inclusive education. Going one step forward the researchers checked the honestly significant difference of the pair-wise comparison within ANOVA results through Tukey's HSD (Honestly Significant Difference). While F statistics confirm whether there is an overall difference between the sample means the T HSD allows the researcher to determine between which of the various pairs of means - if any of them - there is a significant difference. The result shows that the blue value for $\mathrm{Q}$ indicates a significant result.

Table: 4 comparisons within ANOVA results through Tukey's HSD (Honestly Significant Difference).

\begin{tabular}{|c|c|c|c|}
\hline \multicolumn{2}{|c|}{ Pairwise Comparisons } & $\begin{aligned} & \mathrm{HSD}_{.05}=1.0218 \\
& \mathrm{HSD}=1.2736\end{aligned}$ & $Q_{.05}=3.3312 \quad Q_{.01}=4.1522$ \\
\hline$T_{1}: T_{2}$ & $\begin{array}{l}M_{1}=79.91 \\
M_{2}=84.89\end{array}$ & 4.98 & $Q=16.24(p=.00000)$ \\
\hline$T_{1}: T_{3}$ & $\begin{array}{l}M_{1}=79.91 \\
M_{3}=80.09\end{array}$ & 0.18 & $\mathrm{Q}=0.59(p=.90949)$ \\
\hline$T_{2}: T_{3}$ & $\begin{array}{l}M_{2}=84.89 \\
M_{3}=80.09\end{array}$ & 4.80 & $Q=15.65(p=.00000)$ \\
\hline
\end{tabular}

Another treatment of the study was to identify whether the teachers differ significantly in their awareness of Online Education concerning their experience in teaching. This was also analyzed through ANOVA. The results of the analysis are given in the below table.

Table: 5 Awareness of Teachers of Online Education concerning their Teaching Experience

\begin{tabular}{|c|c|c|c|c|}
\hline & 1 & 2 & 3 & Total \\
\hline $\mathrm{N}$ & 100 & 100 & 100 & 300 \\
\hline$\sum \mathrm{X}$ & 7991 & 8489 & 8009 & 24489 \\
\hline Mean & 79.91 & 84.89 & 80.09 & 81.63 \\
\hline$\sum \mathrm{X}^{2}$ & 639483 & 721593 & 642351 & 2003427 \\
\hline Std.Dev. & 3.0521 & 3.1169 & 3.0321 & 3.8317 \\
\hline
\end{tabular}

\begin{tabular}{|c|c|c|c|c|}
\hline \multicolumn{4}{|c|}{ Result Details } & \\
\hline Source & SS & $\mathrm{df}$ & MS & \\
\hline Between-treatments & 1595.76 & 2 & 797.88 & $F=84.80886$ \\
\hline Within-treatments & 2794.17 & 297 & 9.408 & \\
\hline Total & 4389.93 & 299 & & \\
\hline
\end{tabular}

The f-ratio value is 84.80886 . The $p$-value is $<.00001$. The result is significant at $p<.01$. 
The F ratio is found 84.81and accordingly, the P-value is $<.0001$. Therefore, the result is significant at $\mathrm{P}<.01$. It is concluded that so far as the teaching experience is concerned the teachers differ significantly in their awareness level based on their experience in teaching.

Table-6 comparisons within ANOVA results through Tukey's HSD (Honestly Significant Difference).

\begin{tabular}{|c|c|c|c|}
\hline \multirow{2}{*}{\multicolumn{2}{|c|}{ Pairwise Comparisons }} & $\mathrm{HSD}_{.05}=1.0218$ & \multirow{2}{*}{$Q_{.05}=3.3312 \quad Q_{.01}=4.1522$} \\
\hline & & $\mathrm{HSD}_{.01}=1.2736$ & \\
\hline \multirow{2}{*}{$\mathbf{T}_{1}: \mathbf{T}_{2}$} & $\mathrm{M}_{1}=79.91$ & \multirow{2}{*}{4.98} & \multirow{2}{*}{$\mathrm{Q}=16.24(p=.00000)$} \\
\hline & $\mathrm{M}_{2}=84.89$ & & \\
\hline \multirow{2}{*}{$\mathbf{T}_{1}: \mathbf{T}_{3}$} & $\mathrm{M}_{1}=79.91$ & \multirow{2}{*}{0.18} & \multirow{2}{*}{$\mathrm{Q}=0.59(p=.90949)$} \\
\hline & $\mathrm{M}_{3}=80.09$ & & \\
\hline \multirow{2}{*}{$\mathbf{T}_{2}: \mathbf{T}_{3}$} & $\mathrm{M}_{2}=84.89$ & \multirow{2}{*}{4.8} & \multirow{2}{*}{$\mathrm{Q}=15.65(p=.00000)$} \\
\hline & $\mathrm{M}_{3}=80.09$ & & \\
\hline
\end{tabular}

Further, the researcher checked the honestly significant difference of the pair-wise comparison within ANOVA results through Tukey's HSD (Honestly Significant Difference). The result shows that the blue value for Q indicates a significant result.

So far as the attitude of teachers towards the online system of education is concerned the researcher compares the attitude of teachers with several Education backgrounds of the teachers concerning the effectiveness of online education. This was analyzed through ANOVA. The F ratio is found 651.69 and accordingly, the P-value is $<.0001$. Therefore, the result is significant at $\mathrm{P}<.01$. It is concluded that so far as the teaching background is concerned the teachers differ significantly in their attitude on the effectiveness of inclusive education.

Table: 7 Attitude of Teachers of Online Education concerning their Educational Background

\begin{tabular}{|c|c|c|c|c|}
\hline & 1 & 2 & 3 & Total \\
\hline $\mathrm{N}$ & 100 & 100 & 100 & 300 \\
\hline$\sum \mathrm{X}$ & 6942 & 8471 & 7032 & 22445 \\
\hline Mean & 69.42 & 84.71 & 70.32 & 74.817 \\
\hline$\sum \mathrm{X}^{2}$ & 483086 & 718855 & 495396 & 1697337 \\
\hline Std.Dev. & 3.4412 & 3.5909 & 3.0247 & 7.7755 \\
\hline
\end{tabular}

\begin{tabular}{|c|c|c|c|c|}
\hline \multicolumn{5}{|c|}{ Result Details } \\
\hline Source & SS & df & MS & \\
\hline Between-treatments & 14722.2067 & 2 & 7361.1033 & $\mathrm{~F}=651.69499$ \\
\hline Within-treatments & 3354.71 & 297 & 11.2953 & \\
\hline Total & 18076.9167 & 299 & & \\
\hline
\end{tabular}

The f-ratio value is 651.69499. The p-value is $<.00001$. The result is significant at $p<.01$.

Again to check the reliability of the results received from ANOVA the researchers checked the honestly significant difference of the pair-wise comparison within ANOVA results through Tukey's HSD (Honestly Significant Difference). The result shows that the blue value for $\mathrm{Q}$ indicates a significant result.

Table-8 comparisons within ANOVA results through Tukey's HSD (Honestly Significant Difference).

\begin{tabular}{|c|c|c|c|}
\hline \multirow{2}{*}{\multicolumn{2}{|c|}{ Pairwise Comparisons }} & $\mathrm{HSD}_{.05}=1.1196$ & \multirow{2}{*}{$\mathrm{Q}_{.05}=3.3312 \quad \mathrm{Q}_{.01}=4.1522$} \\
\hline & & HSD $_{.01}=1.3955$ & \\
\hline \multirow{2}{*}{$\mathbf{T}_{1}: \mathbf{T}_{2}$} & $\mathrm{M}_{1}=69.42$ & \multirow{2}{*}{15.29} & \multirow{2}{*}{$\mathrm{Q}=45.49(p=.00000)$} \\
\hline & $\mathrm{M}_{2}=84.71$ & & \\
\hline \multirow{2}{*}{$\mathbf{T}_{1}: \mathbf{T}_{3}$} & $\mathrm{M}_{1}=69.42$ & \multirow{2}{*}{0.9} & \multirow{2}{*}{$\mathrm{Q}=2.68(p=.14231)$} \\
\hline & $\mathrm{M}_{3}=70.32$ & & \\
\hline \multirow{2}{*}{$\mathbf{T}_{2}: \mathbf{T}_{3}$} & $\mathrm{M}_{2}=84.71$ & \multirow{2}{*}{14.39} & \multirow{2}{*}{$\mathrm{Q}=42.82(p=.00000)$} \\
\hline & $\mathrm{M}_{3}=70.32$ & & \\
\hline
\end{tabular}


Another treatment of the study was to identify whether the teachers differ significantly in their attitude towards Online Education concerning their experience in teaching. This was also analyzed through ANOVA. The results of the analysis are given in the below table

Table: 9 Attitude of Teachers of Online Education concerning their Teaching Experience

\begin{tabular}{|l|l|l|l|l|}
\hline & 1 & 2 & 3 & Total \\
\hline $\mathrm{N}$ & 100 & 100 & 100 & 300 \\
\hline$\sum \mathrm{X}$ & 8525 & 8012 & 8064 & 24601 \\
\hline Mean & 85.25 & 80.12 & 80.64 & 82.003 \\
\hline$\sum \mathrm{X}^{2}$ & 727917 & 642898 & 651260 & 2022075 \\
\hline Std.Dev. & 3.4241 & 3.1407 & 3.1447 & 3.9694 \\
\hline
\end{tabular}

\begin{tabular}{|l|l|l|l|l|}
\hline \multicolumn{5}{|c|}{ Result Details } \\
\hline Source & SS & df & MS & \\
\hline Between-treatments & 1594.6467 & 2 & 797.3233 & F $=75.98794$ \\
\hline Within-treatments & 3116.35 & 297 & 10.4928 & \\
\hline Total & 4710.9967 & 299 & & \\
\hline
\end{tabular}

Table-10 comparisons within ANOVA results through Tukey's HSD (Honestly Significant Difference).

\begin{tabular}{|c|c|c|c|}
\hline \multicolumn{2}{|c|}{ Pairwise Comparisons } & $\mathrm{HSD}_{.05}=1.0791$ & $Q_{.05}=3.3312$ \\
\hline \multirow{2}{*}{$\mathbf{T}_{1}: \mathbf{T}_{2}$} & $\mathrm{M}_{1}=85.25$ & \multirow{2}{*}{5.13} & $\mathrm{Q}=15.84(p=$ \\
\hline & $\mathrm{M}_{2}=80.12$ & & $.00000)$ \\
\hline \multirow{2}{*}{$\mathbf{T}_{1}: \mathbf{T}_{3}$} & $\mathrm{M}_{1}=85.25$ & \multirow{2}{*}{4.61} & $\mathrm{Q}=14.23(p=$ \\
\hline & $\mathrm{M}_{3}=80.64$ & & .00000) \\
\hline \multirow{2}{*}{$\mathbf{T}_{2}: \mathbf{T}_{3}$} & $\mathrm{M}_{2}=80.12$ & \multirow{2}{*}{0.52} & $\mathrm{Q}=1.61(p=$ \\
\hline & $\mathrm{M}_{3}=80.64$ & & .49322) \\
\hline
\end{tabular}

Again to check the reliability of the results received from ANOVA the researchers checked the honestly significant difference of the pair-wise comparison within ANOVA results through Tukey's HSD (Honestly Significant Difference). The result shows that the blue value for $\mathrm{Q}$ indicates a significant result.

The following graphs emerged from the quantitative data show better visibility in the findings of the study.

Comparison between Mean Awareness of Teachers of Online Teaching

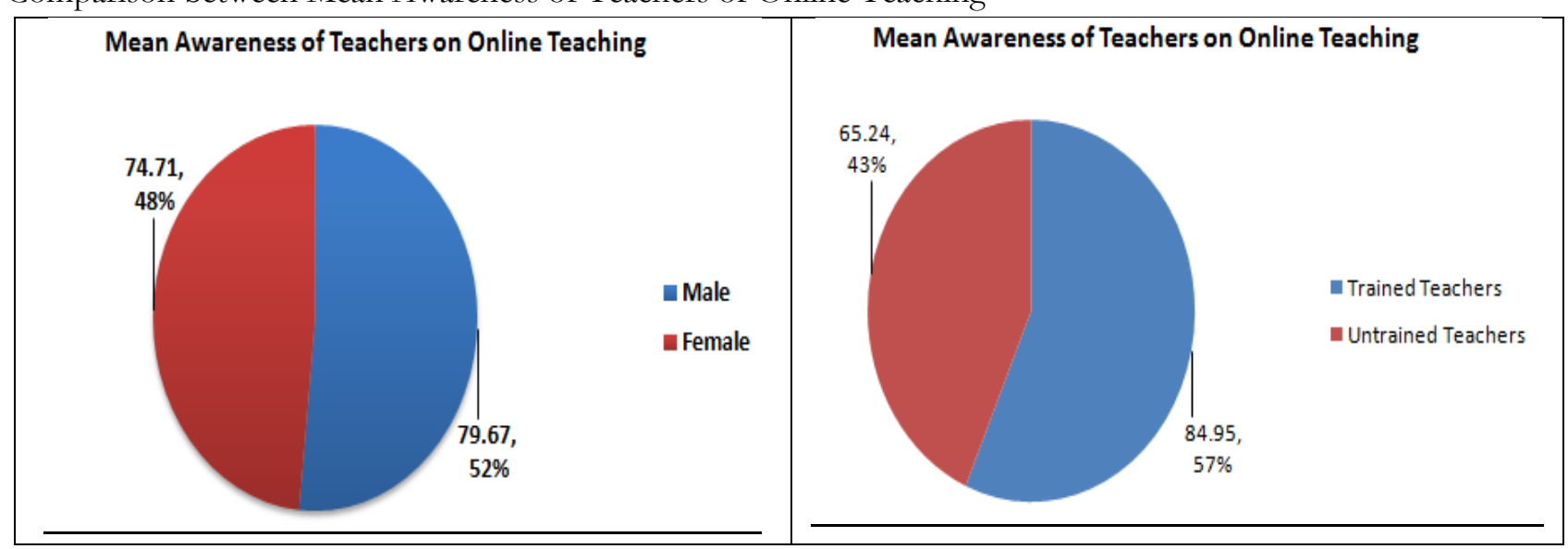




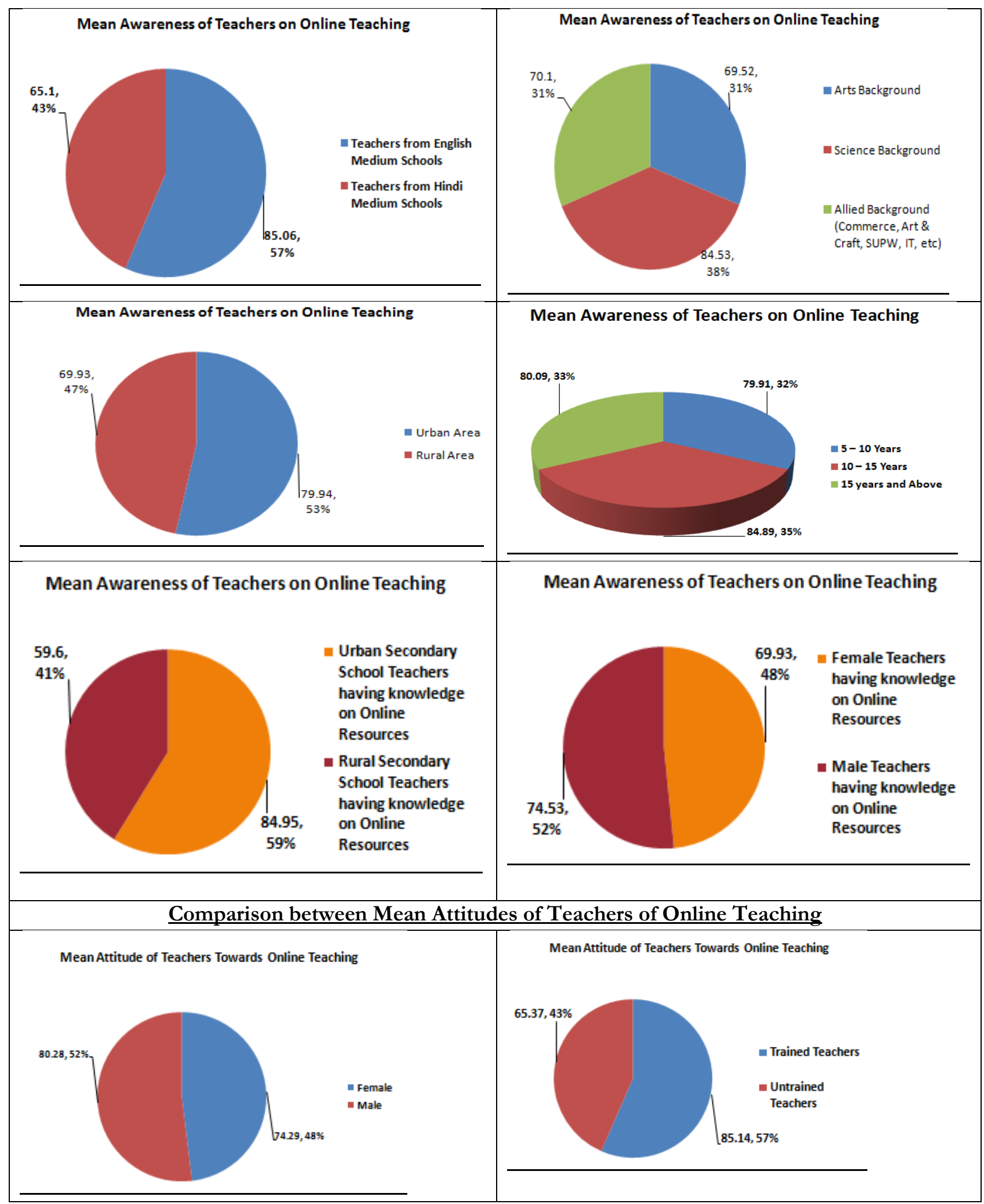




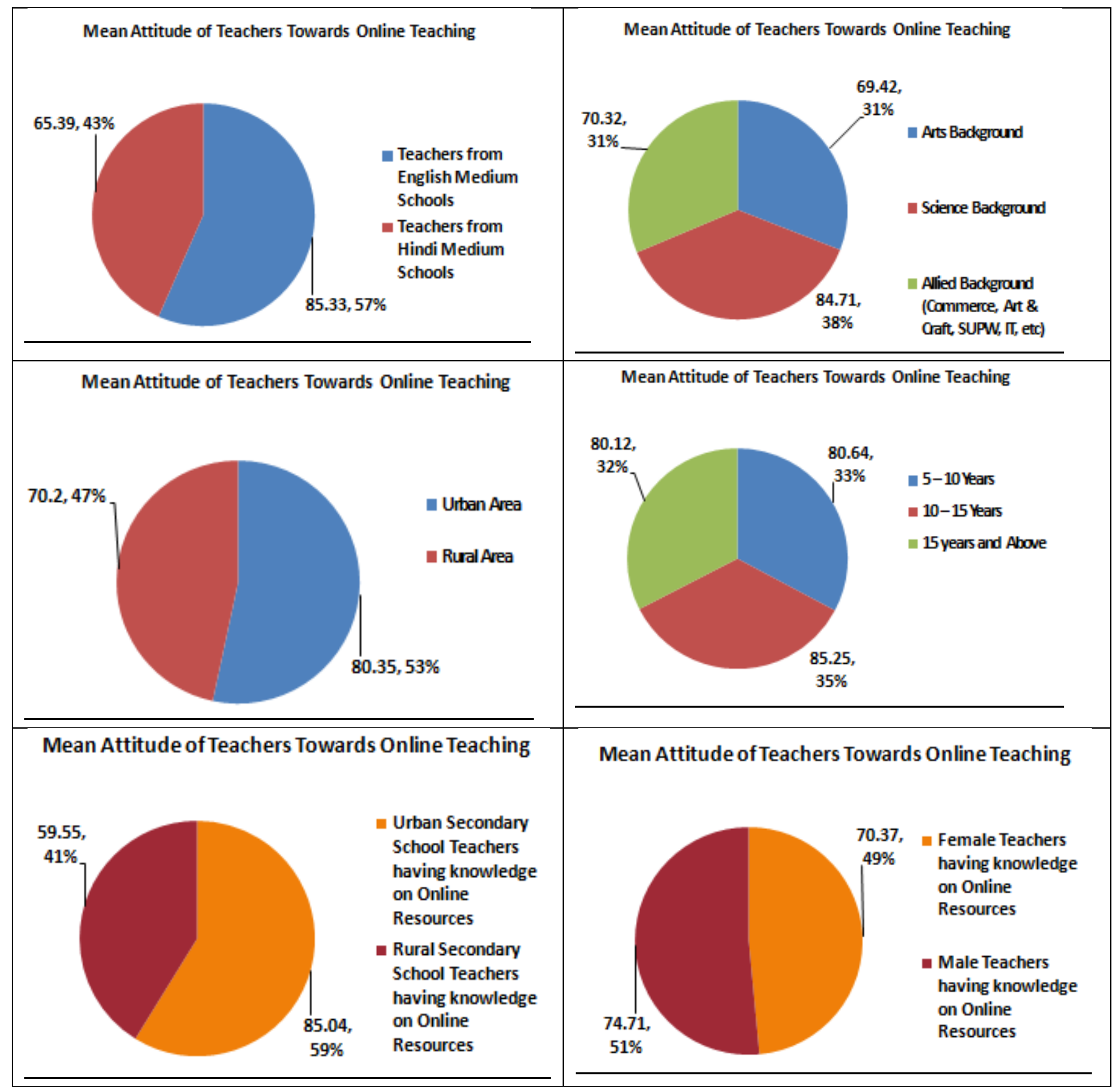

Correlation between Awareness and Attitude of teachers on online Education

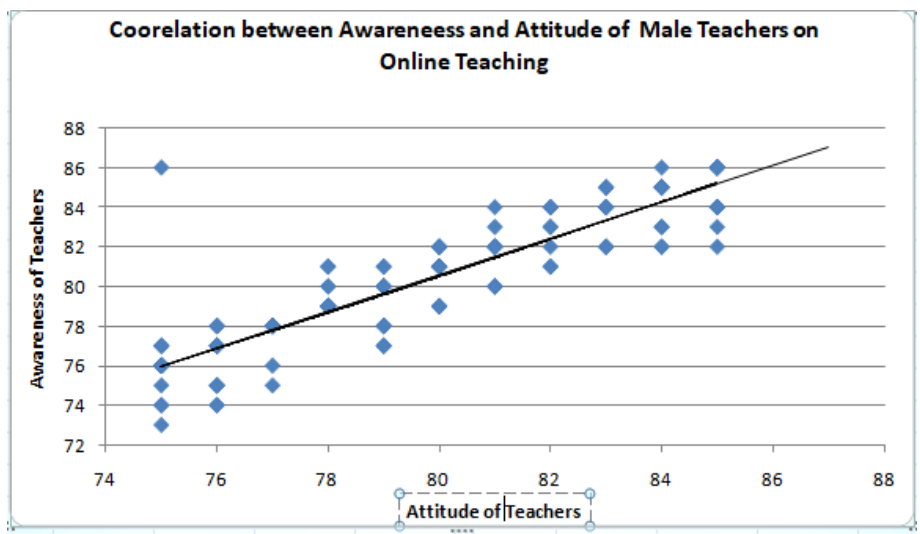



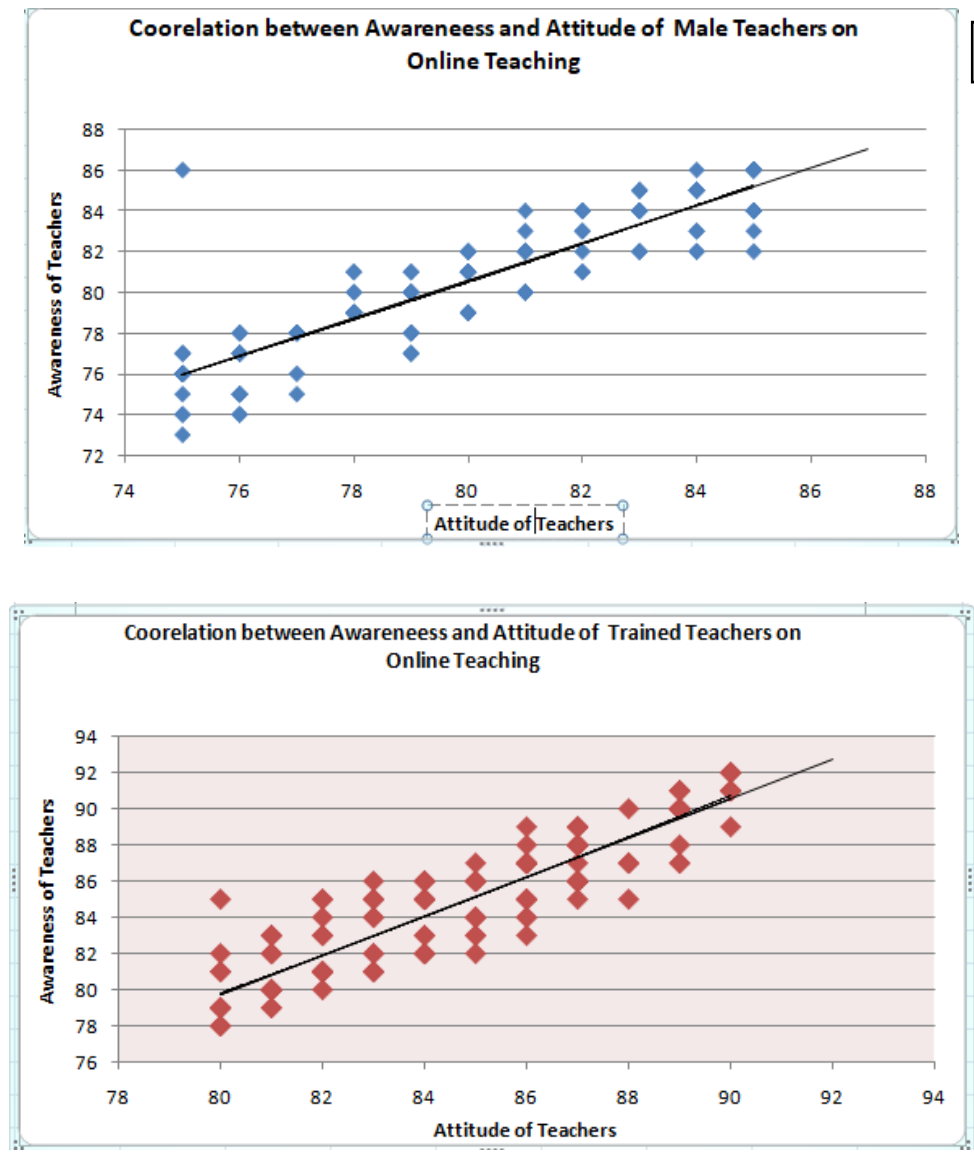

Coorelation between Awareneess and Attitude of Un-trained Teachers on Online Teaching
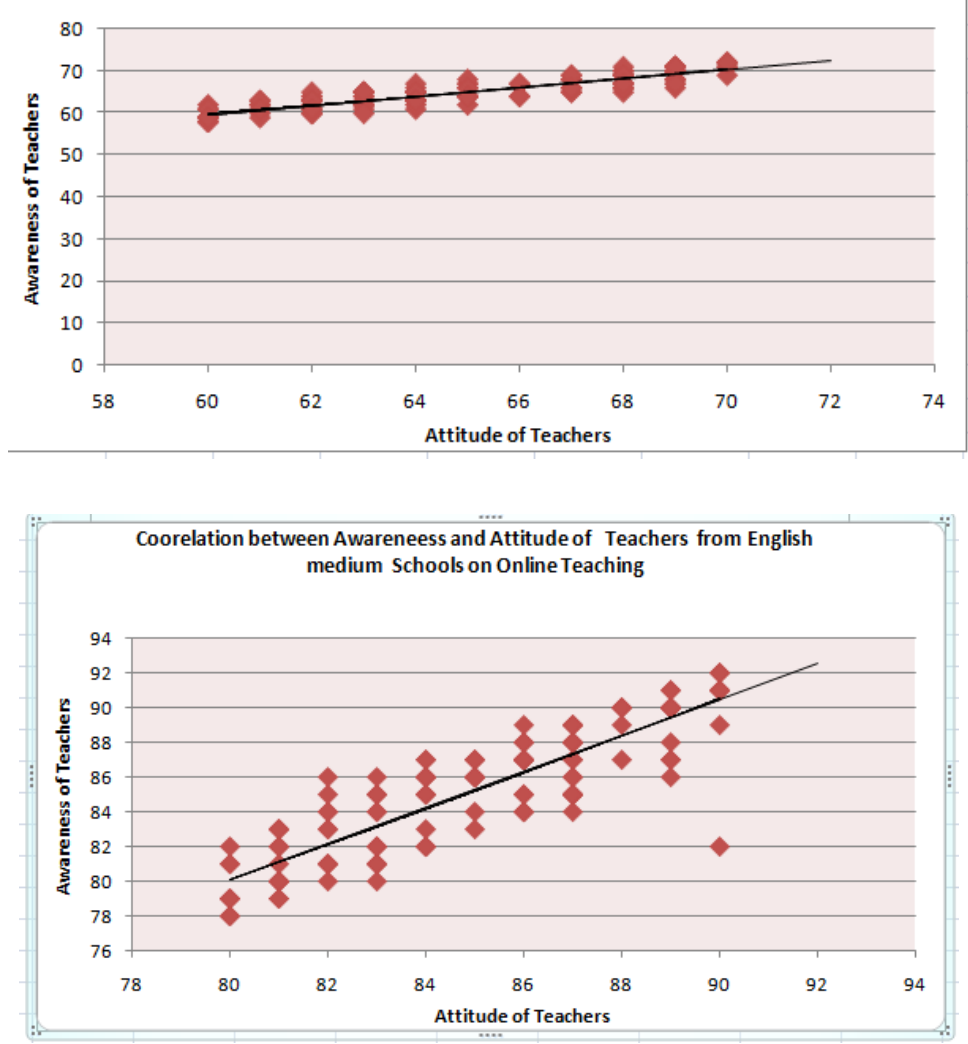

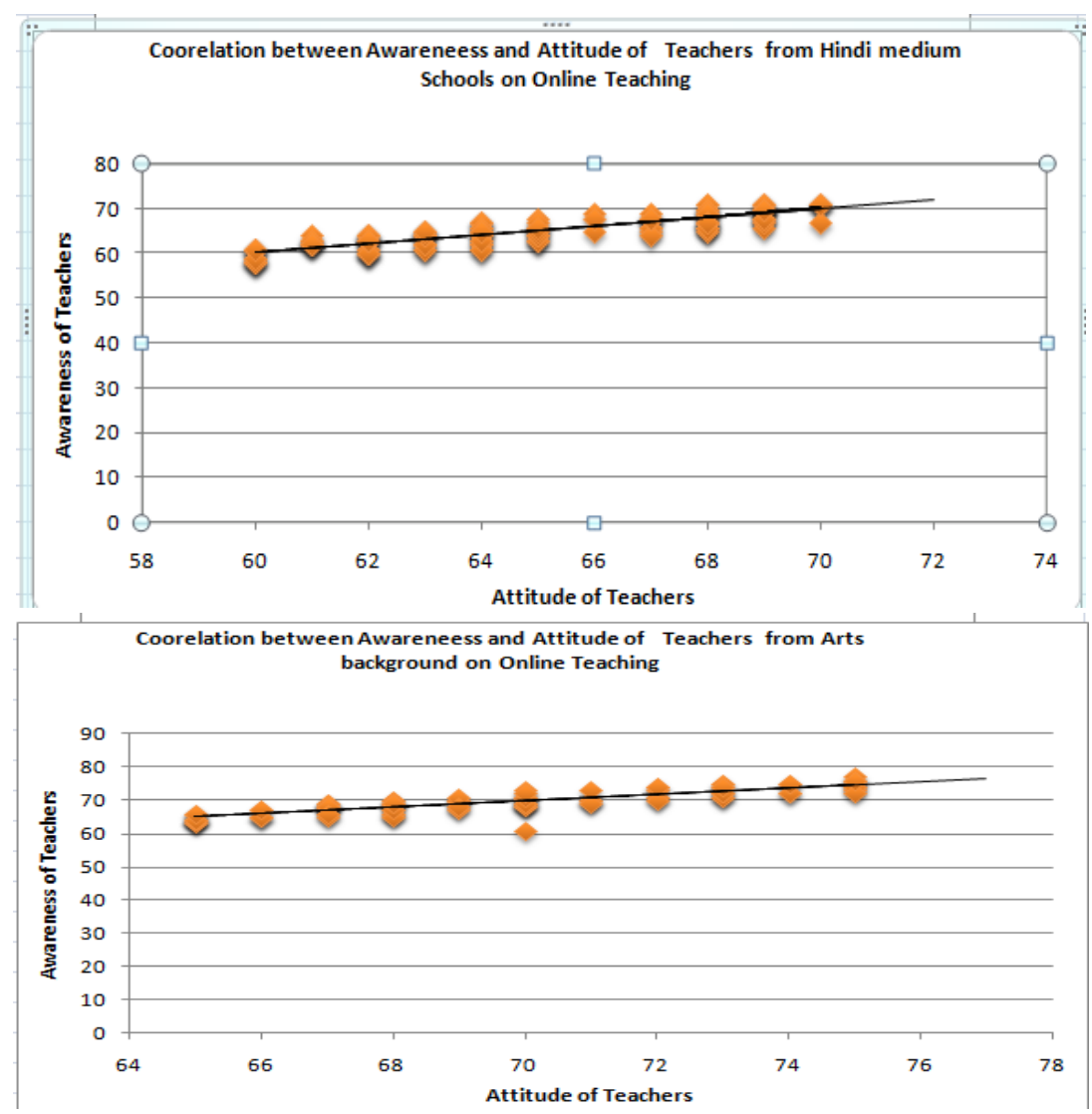

$\mathrm{N}=150$
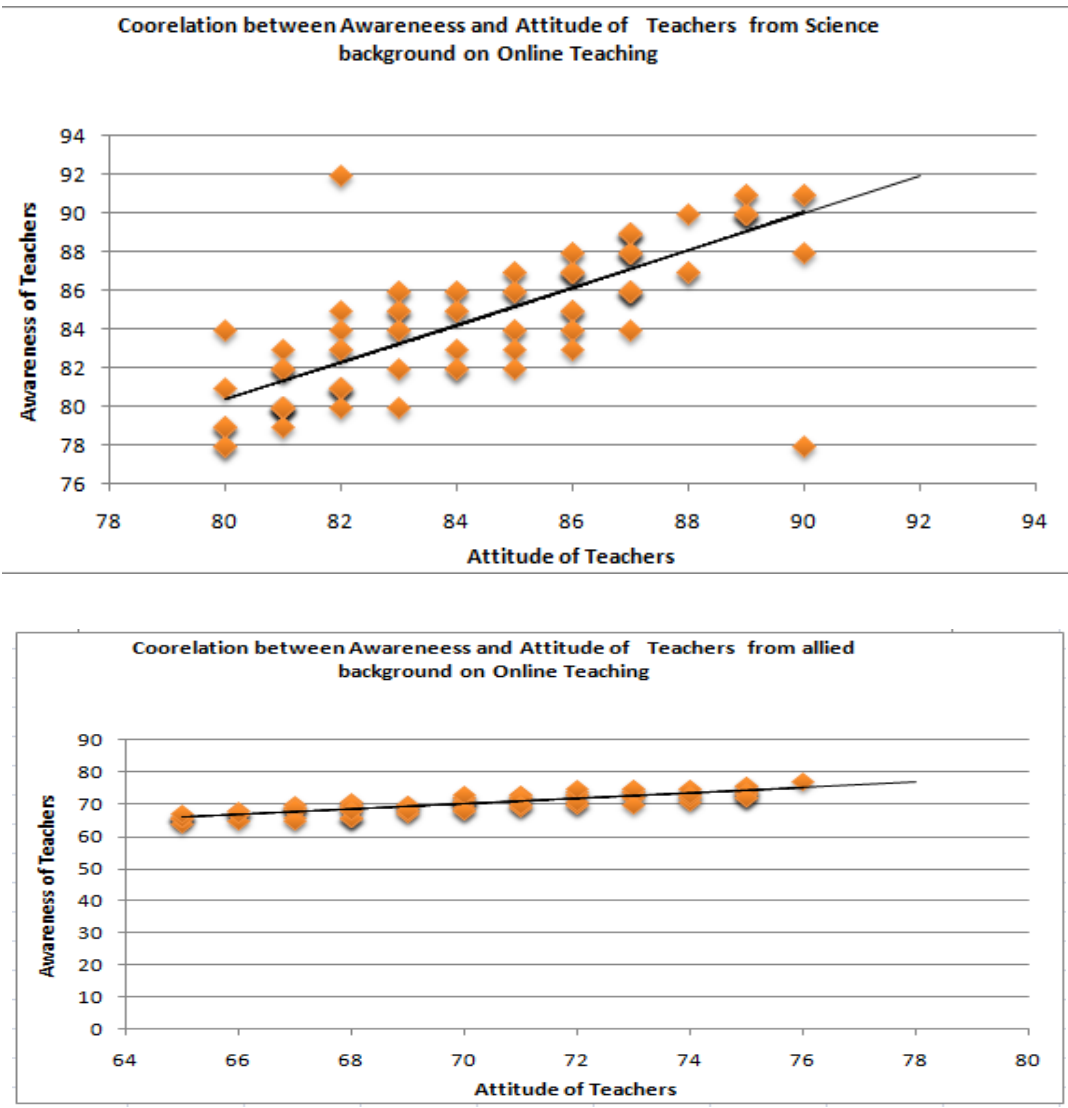

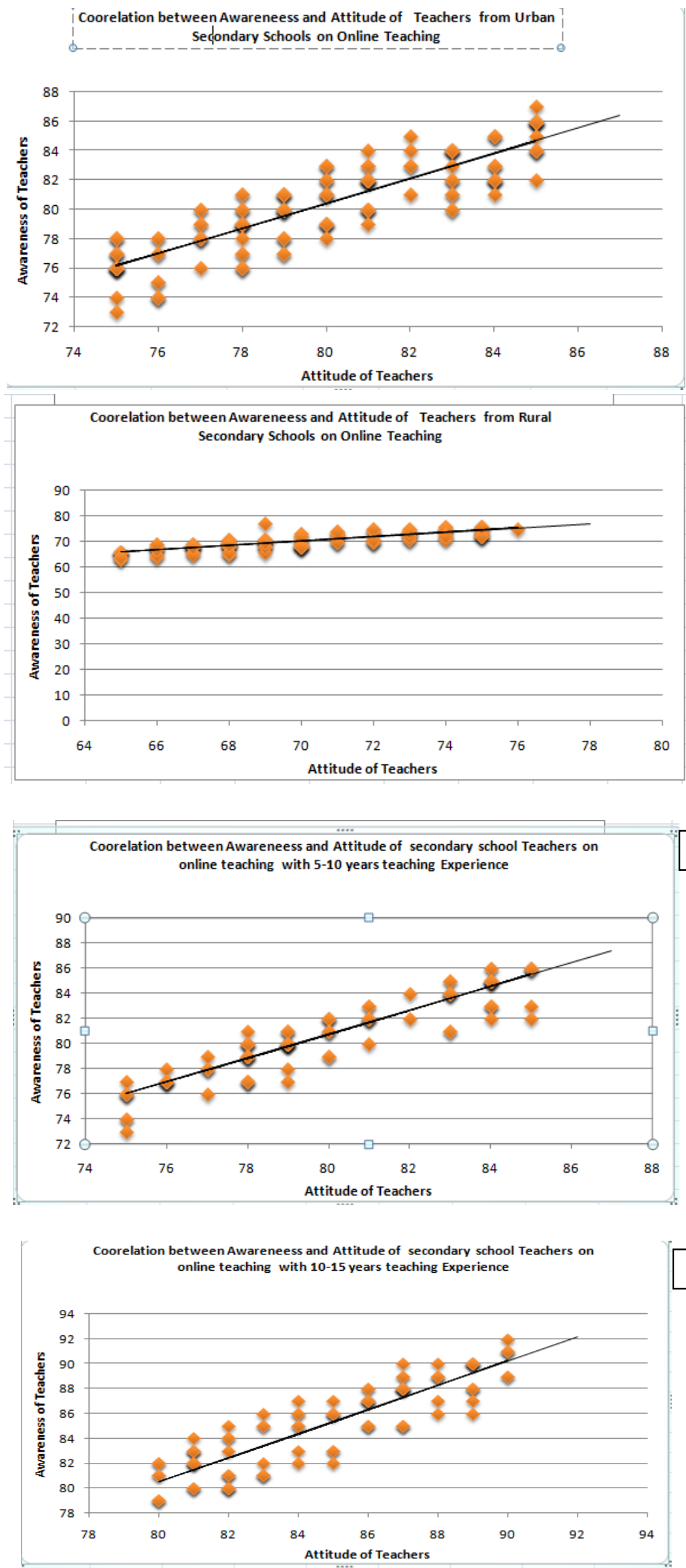
Coorelation between Awareneess and Attitude of secondary school Teachers on online teaching with 15 years and aboveteaching Experience
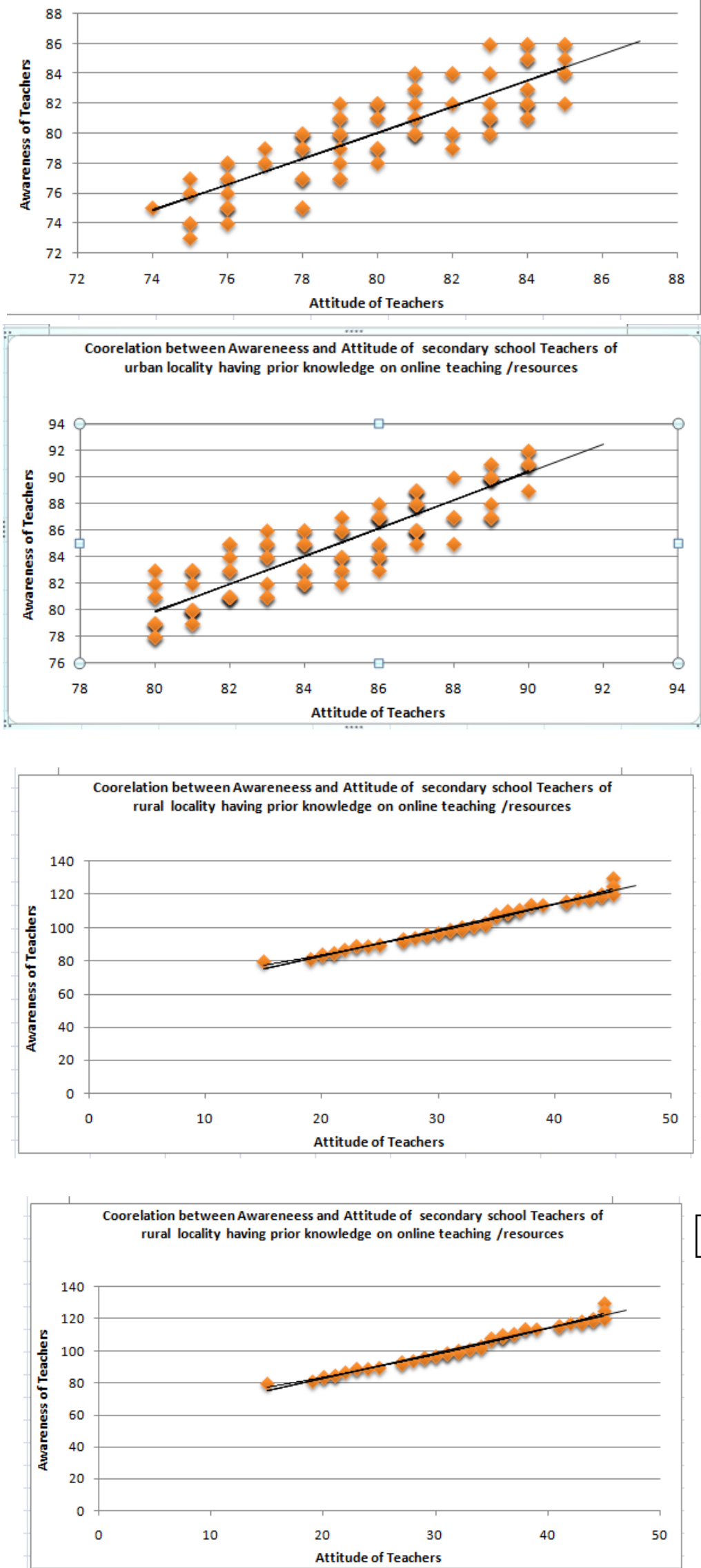


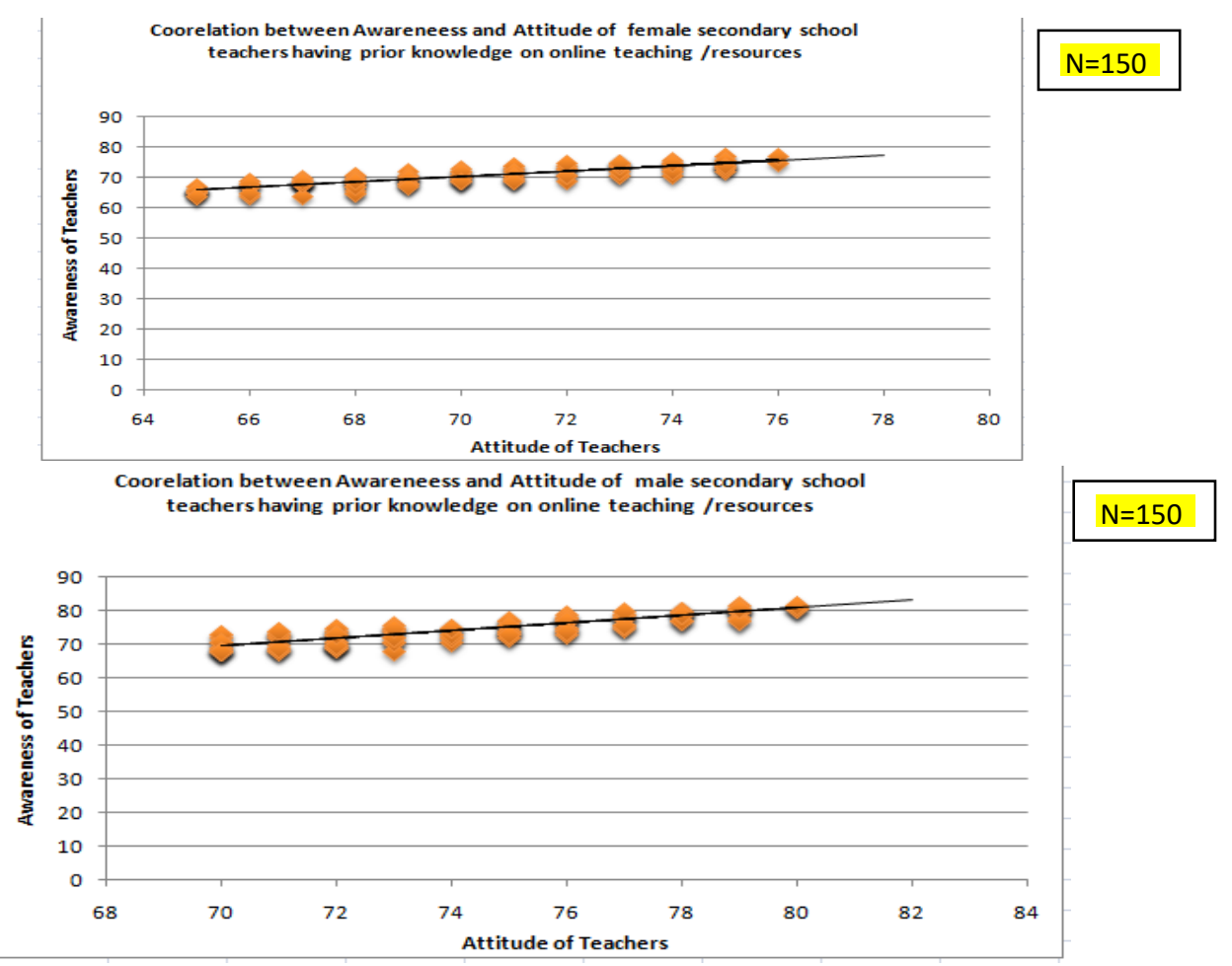

These findings are similar to the findings of many previous researchers such as Dhawan (2020), Katerina, Anastasios (2016), Zhao et.al. (2002), etc. This study also found that the untrained teachers though possess above average in their awareness and attitude towards the effectiveness of the online system of education during the COVID pandemic yet it was much lower than the awareness and attitude level of the teachers who are professionally trained in teaching. This shows the professional training has a very good effect on the awareness and attitude of teachers on the current issues and trends of society. These findings are similar to the findings of the research conducted by Chatterjee \& Chakraborty, 2020; Dhawan, 2020 who found that the curriculum of teacher education programs gives very good exposure to the teachers on the application of educational technology in the educational development of children. Therefore it is important to the school to ensure that all teachers must be professionally trained before their recruitment or as soon as possible immediately after their recruitment as a teacher in the school.

Again it is found the teachers from English medium schools were much better in their awareness in attitude than the teachers of Hindi medium schools. This is because most Hindi medium secondary schools are government schools where the teachers receive less scope to update their knowledge, competencies, concerning new pedagogies and technologies. Many government schools are located in remote areas where the internet connectivity is not very good and the scope of the online system of education is very less. Moreover, the principals of these schools do not take much initiative to send the teachers for orientation programs or refresher courses conducted by NCERT (National Council for Educational Research and Training) and SCERT (State Council for Educational Research and Training) or teachers training institutes. This finding is similar to the finding of the research conducted by Fedynich, L. V. (2014). He found that the teachers who regularly attended the training programs are better in their knowledge and perception towards the e-learning approach to teaching in many countries. The study also reported that teachers from arts and allied backgrounds were less aware of the effectiveness of online education than the teachers of science backgrounds. Though there is not much logical reason behind this finding yet some studies conducted by Hasan, N., \& Bao, Y. (2020) and Kaparounaki, C. K., et. al (2020)reported that teachers from science education backgrounds are more self-motivated and curious towards the innovation of ET than teachers from other educational backgrounds. 
However, to develop the digital competencies of the teachers across disciplines and educational backgrounds the schools must give opportunities to the teachers to participate in the various refresher course and orientation programs on educational technology. Since the knowledge of ET is indispensable for developing the effectiveness and quality of teaching it is recommended that the school must create an online education resource center in the school itself and give mandatory training to all teachers about the pedagogy of online mood of education (Khan, A. H., et.al). Wetzel, K., Wilhelm, L., \& Williams, M. K. (2004) from their study on resource management in education found that in many countries, the government provides huge grants to the schools to implement educational technology on a large scale. But unfortunately, it is found the schools are not very sincere in implementing the educational technology project in their schools.

\section{b) Qualitative Analysis}

The questionnaire on the attitude of teachers towards online teaching had two open-ended questions. The first question was to receive the opinion of the teachers on the strength \& weaknesses of online classes and the second was to get the opinion of the teachers about their suggestions to strengthen the system of online classes. Concerning top, in the first question, $85 \%$ of teachers' urban schools and $64 \%$ of teachers from rural were agreed that online classes were the best decision of the government to save the education of the children during the Covid 19 lockdown period. $76 \%$ of them told that online classes put engage the students and help them to continue their education during this pandemic period. It is identified that only $33 \%$ of teachers were found positive about the benefits of online education for the young children studying in pre-primary classes. $92 \%$ of teachers told that online classes could not give a better outcome for the slow learners and differently able students.

$89 \%$ of teachers stated that due to internet connectivity and lack of smart devices with them, almost $30 \%$ of students could not achieve their learning objectives through an online system. $98 \%$ of teachers appreciated the support of online meeting app, such as ZOOM, Google Meet, go to a meeting, podcast, etc. However, they told the ZOOM app was the most popular learning app among the others. $95 \%$ of teachers told that the credibility of assessment through the online system was not reliable. Because the answer script of the students lacks, originality \& creativity. Almost $75 \%$ of students were engaged taking help from the internet to answer the question. $72 \%$ of teachers told that the quality of interaction through online classes was not optimum. So far as the attendance of the students in the online classes is concerned, it was identified that approximately $70 \%$ of students were attending the classes. $93 \%$ of teachers told that about $76 \%$ of students staying in rural or remote areas could not get the benefits from online classes, because of poor internet connectivity, electricity problem, and unable to afford a Smartphone by the parents.

$79 \%$ of teachers suggested that the training of teachers to conduct online classes is vital to ensure its quality \& effectiveness. $73 \%$ of teachers told that every teacher should record their online classes and upload the same on their YouTube account. So that the students who miss the class due to some personal/technical problems can get benefits from this. $81 \%$ of teachers suggested that instructional \& course planning is very important in conducting online classes. While planning the lecture/ presentation the teacher must consider the individual differences of the class and plan the content accordingly. $83 \%$ of teachers suggested that the school should provide study material to the students. Since many of them may not receive the content online. Therefore, the school should create its Moodle account and give the webspace to each student from class six onwards. Regarding the assessment method, $91 \%$ of teachers told that the assessment should be conducted unit-wise. So that the curriculum load can be reduced and the students will remain free from stress/depression. $76 \%$ of teachers told that to maximize the outcomes of online teaching, it is important to involve the parents. Therefore, the school should organize parent's teacher meetings at least twice a month to understand the challenges faced by the students.

Many teachers told that in India the e-learning project is not a new project. Recently it was started in 2014 but stopped in 2019 because the fund was not released by the government to the schools as the Govt. realized that 
there was huge corruption in this project. As a result, the amount which was invested in the project for the hardware, software, equipment, staff appointment, and training was wasted without any outcome. Teachers, mostly from the schools located in rural areas are found not aware of the online resources available freely on the website of NCERT, NCTE, NEUPA, NIET, SIET, DIET, etc. They are not aware of MOOCS (Massive Open Online Courses) and CPD (Continuous Professional Development) and the application of ICT in education.

\section{Implications of the Study}

The present research describes the importance of developing awareness and attitude of teachers' towards the effectiveness of online education in the triangular periphery, such as teaching, learning \& assessment. This is required because the online education system is a technology-driven work practice and has advantages \& limitations. Researchers like Morrison et al, 2007 reported, since online education can serve a very large group of learners sitting anywhere in the globe. It encourages self laboratory learning. The online system, similar to other educational systems, considers the input, the process, and the output practices. Planning for Training of the teachers to teach through online mode, curriculum, assessment method \& practical work, etc are the input variables for the online education system. So far as the process is concerned the internet connectivity issue, the curriculum transaction method, the management of the feedback of the stakeholders, the individualized instruction, and meeting the expectation of the stakeholders are included. The outcome of the system considers the achievements of students in grasping the course learning outcomes (CLOs) and program learning outcomes (PLOs). Therefore, the system approach to online education requires the development of strategies by considering the feedback \& suggestion of the stakeholders. This is a very comprehensive area for future researchers who would like to research the online system of education.

This article also describes the strength, weaknesses, opportunities \& threats. From the literature review, the strength \& weaknesses of online education were identified but the opportunities that can be possible from the system of online education are not described by the previous researchers. Similarly in the previous research papers, the threats to online education are not also discussed by the researcher. The above two areas are having ample scope for future researchers. The present research, therefore, opened a wide research scope not only for the researchers from the field of education but also from the corporate and companies.

Because during the COVID-19 pandemic online system was the only savior of the economy to create technologydriven work practice. Thus this research will open many new dimensions for the future researcher to research on the system approach of digital transformations, pedagogical transformation \& psychological transformation to create mass awareness among the public across countries, community, education, profession, and standard of living.

The study also found a few drawbacks of online education during the COVID pandemic that affected the mental and emotional health of the learners. Through the open-ended questions, the teachers reported that due to the pandemic many people lost their jobs or earned less. Therefore, many parents could not provide a smart-phone to their children, which was required for their online teaching. Many students, who are staying in a remote location, were reported facing internet connectivity issues. These challenges hamper their smoothness of learning. As a result, many students were found suffering from stress and anxiety. Similar findings were reported by many previous researchers, such as Cao, et al, (2020), Yilmaz, A. B. (2019), Patricia, A. (2020).

\section{Conclusion}

Our results showed that the online system of education has both positive and negative impacts on the stakeholders of education. Though it has created many opportunities yet it has also opened huge challenges for the stakeholders. If we want to improve the quality of the online system, we have to address these challenges by involving the stakeholders. 


\section{Ethical Statements}

The study was reviewed and approved by all participants and all were given their consent for submitting it for publication.

\section{Declaration of Conflicting Interests}

The author declared no potential conflicts of interest concerning the research, authorship, and/or publication of this article.

\section{Funding}

The author received no financial support for the research, authorship, and/or publication of this article.

\section{Reference}

Bignoux, S., \& Sund, K. J. (2018) Tutoring executives online: What drives perceived quality? Behaviour \& Information Technology, 37(7), 703-713. https://doi.org/10.1080/0144929X.2018.1474254

Bojovic, Z., Bojovic, P. D., Vujosevic, D., \& Suh, J. (2020). Education in times of crisis: Rapid transition. DOI: $10.1002 /$ cae.22318.

Carroll, N., \& Conboy, K. (2020). Normalizing the "new normal": Changing tech-driven work practices under pandemic time pressure. International Journal of Information Management, 55, 102186. https://doi.org/10.1016/j.ijinfomgt.2020. 102186.

Cevher-Kalburan, N. (2011). Early childhood teachers' thoughts and practices about the use of computers in early childhood education. Procedia Computer Science, 3, 1562-1570. doi:10.1016/j.procs.2011.01.050.

Chatterjee, I., \& Chakraborty, P. (2020). Use of information and communication technology by medical educators amid COVID-19 pandemic and beyond. Journal of Educational Technology Systems in press. DOI: 10.1177/0047239520966996.

Chen, J., \& Chang, C. (2006). Using computers in early childhood classrooms: Teachers' attitudes, skills, and practices. Journal of Early Childhood Research, 4(2), 169-188. DOI: 10.1177/1476718X06063535.

Copeland, W. E., McGinnis, E., Bai, Y., Adams, Z., Nardone, H., Devadanam, V.Hudziak, J. J. (2020). Impact of COVID on college student mental health and wellness. Journal of the American Academy of Child \& Adolescent Psychiatry in press. PMID: 33091568, PMCID: PMC8173277, DOI: 10.1016/j.jaac.2020.08.466

Dhawan, S. (2020). Online learning: A panacea in the time of COVID-19 crisis. Journal of Educational Technology Systems, 49(1), 5-22. DOI: 10.1177/0047239520934018.

Dhawan, S. (2020). Online learning: A panacea in the time of COVID-19 crisis. Journal of Educational Technology Systems, 49(1), 5-22. DOI: 10.1177/0047239520934018.

Essadek, A., \& Rabeyron, T. (2020). Mental health of French students during the Covid-19 pandemic. Journal of Affective Disorders, 277, 392-393. https://doi.org/10.1016/j.jad.2020.08.042.

Essadek, A., \& Rabeyron, T. (2020). Mental health of French students during the Covid-19 pandemic. Journal of Affective Disorders, 277, 392-393. https://doi.org/10.1016/j.jad.2020.08.042.

Fedynich, L. V. (2014). Teaching beyond the classroom walls: The pros and cons of cyberlearning. Journal of Instructional Pedagogies, 13, 1. https ://www.aabri .com/manuscript s/13170 1.pdf. ERIC Number: EJ1060090

Fedynich, L. V. (2014). Teaching beyond the classroom walls: The pros and cons of cyberlearning. Journal of Instructional Pedagogies, 13, 1. https ://www.aabri .com/manuscript s/13170 1.pdf. ERIC Number: EJ1060090 
Garrison, D. R., Anderson, T., \& Archer, W. (2001). Critical thinking, cognitive presence, and computer conferencing in distance education. American Journal of Distance Education, 15(1), 7-23. DOI: 10.1080/08923640109527071.

Hasan, N., \& Bao, Y. (2020), Impact of "e-learning crack-up" perception on psychological distress among college students during COVID-19 pandemic: A mediating role of "fear of academic year loss". Children and Youth Services Review, 118, 105355. https://doi.org/10.1016/j.childyouth.2020.105355.

Islam, M. A., Barna, S. D., Raihan, H., Khan, M. N. A., \& Hossain, M. T. (2020). Depression and anxiety among university students during the COVID-19 pandemic in Bangladesh: A web-based cross-sectional survey. PLoS One, 15(8), e0238162. https://doi.org/10.1371/journal.pone.0238162.

Jiang, R. (2020). Knowledge, attitudes, and mental health of university students during the COVID-19 pandemic in China. Children and Youth Services Review, 119, 105494. https://doi.org/10.1016/j.childyouth.2020.105494.

Kalogiannakis, M. (2010). Training with ICT for ICT from the trainer's perspective. A local ICT teacher training experience. Education and Information Technologies, 15(1), 3-17. DOI 10.1007/s10639-008-9079-3.

Kaparounaki, C. K., Patsali, M. E., Mousa, D. P. V., Papadopoulou, E. V., Papadopoulou, K. K., \& Fountoulakis, K. N. (2020). University students' mental health amidst the COVID-19 quarantine in Greece. Psychiatry Research, 290, 113111. https://doi.org/10.1016/j.psychres.2020.113111.

Kaparounaki, C. K., Patsali, M. E., Mousa, D. P. V., Papadopoulou, E. V., Papadopoulou, K. K., \& Fountoulakis, K. N. (2020). University students' mental health amidst the COVID-19 quarantine in Greece. Psychiatry Research, 290, 113111. https://doi.org/10.1016/j.psychres.2020.113111.

21. Katerina, Maria, Anastasios (2021), Development and validation of a students' remote learning attitude scale (RLAS) in higher education. https://doi.org/10.1007/s10639-021-10586-0.

Kerry, T., \& Farrow, J. (1996). Changes in initial teacher training: Students' perceptions of the effectiveness of schoolbased mentoring over time. Educational Studies, 22, 99-110. URL: http://dx.doi.org/10.1080/0305569960220108

Khan, A. H., Sultana, M. S., Hossain, S., Hasan, M. T., Ahmed, H. U., \& Sikder, M. T. (2020). The impact of COVID-19 pandemic on mental health \& wellbeing among home-quarantined Bangladeshi students: A cross-sectional pilot study. Journal of Affective Disorders, 277, 121-128. https://doi.org/10.1016/j.jad.2020.07.135.

Konca, A. S., Ozel, E., \& Zelyurt, H. (2016). Attitudes of preschool teachers towards using information and communication technologies (ICT). International Journal of Research in Education and Science (IJRES), 2(1), 10 15. DOI: $10.21890 /$ ijres.21816.

Lassoued, Z., Alhendawi, M., \& Bashitialshaaer, R. (2020). An exploratory study of the obstacles for achieving quality in distance learning during the COVID-19 pandemic. Education Sciences, 10(9), 232. doi:10.3390/educsci10090232.

Lembani, R., Gunter, A., Breines, M., \& Dalu, M. T. B. (2020). The same course, different access: The digital divide between urban and rural distance education students in South Africa. Journal of Geography in Higher Education, 44(1), 70-84. http://dx.doi.org/doi:10.1080/03098265.2019.1694876.

Lindahl, M. G., \& Folkesson, A. M. (2012). ICT in preschool: Friend or foe? The significance of norms in changing practice. International Journal of Early Years Education, 20(4), 422-436. DOI: 10.1080/09669760.2012.743876.

Mishra, L., Gupta, T., \& Shree, A. (2020). Online teaching-learning in higher education during lockdown period of COVID-19 pandemic. International Journal of Educational Research Open in press. https://doi.org/10.1016/j.ijedro.2020.100012.

Nguyen, N. T. (2013). Technology Acceptance and Performance in Online Learning Environments: Impact of SelfRegulation. Journal of Online Learning and Teaching, 9(1), 116-130.

Patricia, A. (2020). College students' use and acceptance of emergency online learning due to COVID-19. International Journal of Educational Research Open in press. https://doi.org/10.1016/j.ijedro.2020.100011. 
Patricia, A. (2020). College students' use and acceptance of emergency online learning due to COVID-19. International Journal of Educational Research Open in press.

Peters, M. A., Wang, H., Ogunniran, M. O., Huang, Y., Green, B., Chunga, J. O., ... Khomera, S. W. (2020). China's internationalized higher education during COVID-19: Collective student autoethnography. Postdigital Science and Education, 2(3), 968-988. https://doi.org/10.1007/s42438-020-00128-1.

Savage, M. J., James, R., Magistro, D., Donaldson, J., Healy, L. C., Nevill, M., \& Hennis, P. J. (2020). Mental health and movement behavior during the COVID-19 pandemic in UK university students: Prospective cohort study. Mental Health and Physical Activity, 19, 100357.

Schroeder, V. M., \& Kelley, M. L. (2010). Family environment and parent-child relationships as related to executive functioning in children. Early Child Development and Care, 180(1), 1285-1298. DOI: $10.1080 / 03004430902981512$.

Stephen, C., \& Plowman, L. (2008). Enhancing learning with information and communication technologies in pre-school. Early Child Development and Care, 178(6), 637-654. DOI: 10.1080/03004430600869571.

Wedenoja, L. (2020). What to expect when you weren't expecting online classes. Rockefeller Institute of Government. https ://rocki nst.org/blog/what-to-expec t-when-you-were expecting-online-classes.

Wetzel, K., Wilhelm, L., \& Williams, M. K. (2004). The introductory technology course: A tool for technology integration. Contemporary Issues in Technology and Teacher Education, 3, 453-465.

Yildiz, E. P., \& Işman, A. (2016). Quality content in distance education. Universal Journal of Educational Research, 4(12), 2857-2862.DOI: 10.13189/ujer.2016.041220.

Yilmaz, A. B. (2019). Distance and face-to-face students' perceptions towards distance education: A comparative metaphorical study. Turkish Online Journal of Distance Education-TOJDE, 20(1), 1302-6488. https ://files .eric.ed.gov/full Text/EJ120 1959.pdf. ORCID: https://orcid.org/0000-0002-9971-2440.

Youn, M. H., Leon, J., \& Lee, K. J. (2012). The influence of maternal employment on children's learning growth and the role of parental involvement. Early Childhood Development and Care, 182(9), 1227-1246. 